\title{
Peran Direktorat Lalu Lintas Polda Sumatera Utara Dalam Menciptakan Akuntabilitas Pelayanan Publik
}

\section{Role Of The Directorate Traffic, North Sumatera Polda In Creating Accountability of Public Service}

\author{
Muhammad Ikhwan*, Alpi Sahari \& Ahmad Fauzi
}

\author{
Program Magister Ilmu Hukum, Universitas Muhammadiyah Sumatera Utara, Indonesia \\ Diterima: 30 Juni 2020; Disetujui: 02 Agustus 2020; Dipublish: 04 Agustus 2020 \\ *Email:mi7212158@gmail.com
}

\begin{abstract}
Abstrak
Polri khususnya melaksanakan fungsi di bidang Registrasi dan Identifikasi Kendaraan Bermotor (Regident Ranmor) telah berusaha keras memperbaiki diri dengan mengambil langkah-langkah reformasi menuju Polri yang bermoral, profesional, modren, dan mandiri melalui e-goverment system pada pelayanan publik, penelitian ini bertujuan untuk menganalisis peran direktorat lalu lintas Polda Sumatera Utara dalam menciptakan akuntabilitas pelayanan publik dan upaya dalam menciptakan akuntabilitas pelayanan publik oleh direktorat lalu lintas polda sumatera utara. Hasil penelitian ini menunjukkan bahwa regident lantas merupakan salah satu fungsi kepolisian di bidang lalu lintas yang memiliki tugas merupakan salah satu fungsi kepolisian dibidang lalu lintas yang memberikan pelayanan kepada masyarakat di bidang pelayanan administrasi kendaraan bermotor, yaitu penerbitan (SIM STNK, STCK, BPKB), pembinaan materil (SIM, STNK, BPKB, TNKB). Pelayanan publik di bidang registrasi dan identifikasi kendaraan bermotor yang dilakukan oleh Direktorat Lalu Lintas Polda Sumatera Utara berbasis kepuasan masyarakat, untuk itu diharapkan agar dilakukannya survey kepada masyarakat yang dilaksanakan secara periodik (minimal 1 tahun sekali) untuk mengetahui harapan, keinginan masyarakat terhadap pelayanan yang diberikan guna memberikan pelayanan prima kepada masyarakat.
\end{abstract}

Kata Kunci: Peran Direktorat Lalu Lintas, Akuntabilitas, Pelayanan Publik.

\begin{abstract}
The National Police in particular carries out functions in the field of Registration and Identification of Motorized Vehicles (Regident Ranmor) who have strived to improve themselves by taking steps to reform the police that are moral, professional, modren, and independent through e-government systems in public services, this study aims to analyze the role of the North Sumatra Regional Police traffic directorate in creating public service accountability and efforts in creating public service accountability by the North Sumatra regional police traffic directorate. The results of this study indicate that the regent then is one of the functions of the police in the field of traffic which has the task of being one of the functions of the police in the field of traffic which provides services to the public in the field of motor vehicle administration services, namely issuance (SIM STNK, STCK, BPKB), material training (SIM, STNK, BPKB, TNKB). Public services in the field of registration and identification of motor vehicles carried out by the Directorate of Traffic of the North Sumatra Regional Police based on community satisfaction, it is expected that a survey of the community is carried out periodically (at least once a year) to find out the hopes, desires of the community for the services provided in order to provide excellent service to the community.
\end{abstract}

Keywords: The Role of the Directorate of Traffic, Accountability, Public Services.

How to Cite: Ikhwan, M, Sahari, A , \& Fauzi, A (2020). Peran Direktorat Lalu Lintas Polda Sumatera Utara Dalam Menciptakan Akuntabilitas Pelayanan Publik. Journal of Education, Humaniora and Social Sciences (JEHSS). 3 (1): 127-131. 


\section{PENDAHULUAN}

Tuntutan masyarakat untuk terciptanya tata kelola pemerintahan terutama pada sektor pelayanan publik yang dilandasi good governance mengharuskan institusi Polri sebagai sub sistem di bidang pelayanan publik dituntut untuk bertanggungjawab dalam pelaksanaan tugas secara profesional dan akuntable. Untuk itu Polri dituntut sedini mungkin secara terus-menerus dari waktu-kewaktu untuk senantiasa meningkatkan mutu pelayanan yang transparansi dengan artian pelayanan yang diberikan kepada masyarakat dilaksanakan secara cepat, tepat, tindak berbelitbelit, komunikatif, profesionali dan proporsional, serta berorientasi pada masyarakat.

Polri khususnya melaksanakan fungsi dibidang Registrasi dan Identifikasi Kendaraan Bermotor (Regident Ranmor) telah berusaha keras memperbaiki diri dengan mengambil langkahlangkah reformasi menuju Polri yang bermoral, profesional, modern dan mandiri melalui $e$ governace dengan melakuakan pembenahan berkelanjutan pada tataran instrumental struktural dan kultural khususnya dalam proses pelayanan melalui pelaksanaan program unggulan Polri (Quick Wins) yakni peningkatan layanan publik polri tehadap pelanggaran dalam bentuk quick respons sebagai bentuk perubahan budaya Polri yang menitik beratkan pada responsifitas secara tepat, tanggap terhadap permasalahan pelanggan terhadap pelayanan publik dan zero complain dengan meminimalisasi keluhan pelanggan terhadap pelayanan dan kecintaan publik kepada institusi Polri dalam waktu yang relatif cepat berdasarkan standart mutu.

Salah satu program dari Quick Wins tersebut adalah transparansi di bidang Regident Ranmor dengan mengedepankan standar mutu layanan sebagaimana digariskam dalm ISO 9001:200 yang perlu dilakukan revitalisasi kembali penerapan sistem quality management terhadap pelayanan di bidang regident Ranmor akan mengarah pada tingkat kepuasan maysarakat yang didasarkan pada standart mutu layanan. Hal ini dilandasi dari beberapa pertimbangan sebagai berikut, transcedent quality, product-based quality, user based quality, manufacturing-based quality, valuebased quality (Freddy, 2008). Berdasarkan uraian di atas, maka yang menjadi perhatian penulis dalam upaya mewujudkan profesionalisme Polri terkait fungsi Regident Ranmor di Direktorat Lalu Lintas Polda Sumatera Utara melalui revitalisasi quality management system pelayanan Regident Ranmor secara optimal adalah mengakselerasi perubahan budaya Polri secara transparansi dan akuntabilitas pelayanan publik.

\section{METODE PENELITIAN}

Metode yang digunakan dalam dalam penelitian ini adalah penelitian hukum normatif yang bersifat kualitatif. Hal ini disebabkan data yang dianalisis bersifat menyeluruh dan merupakan suatu kesatuan yang bulat (holistik), dimana keanekaragaaman datanya harus didukung dengan informasi yang mendalam (indepth information) (Mendelson, 1979). Menurut Bismar Nasution berpendapat bahwa penelitian hukum normatif adalah penelitian yang mengacu pada normanorma hukum yang terdapat dalam peraturan perundang-undangan dan putusan pengadilan. (Bismar, 2003) pendekatan yang digunakan dalam penelitian ini adalah studi perbandingan (comparative study), dimana penelitian ini dilakukan terkait dengan peran Direktorat Lalu Lintas Polda Sumatera Utara dalam menciptakan akuntabilitas pelayanan publik oleh karena itu analisis dilakukans ecara mikro (microcomparison) (Konrad \& Kotz, 1987), dimana seorang peneliti memungkinakan untuk memanfaatkan hasil-hasil temuan ilmu hukum empiris dan ilmu-ilmu lain untuk kepentingan dan analisis serta eksplanasi hukum tanpa merubah karakter ilmu hukum sebagai ilmu normatif.

\section{HASIL DAN PEMBAHASAN \\ Peran Direktorat Lalu Lintas Polda Sumatera Utara Dalam Menciptakan Akuntabilitas Pelayanan Publik}

Melaksanakan fungsi di bidang Registerasi Kendaraan Bermotor (Regindent Ranmor) khususnya Polri terlah berusaha keras memperbaiki diri dengan mengambil langkah-langkah reformasi menuju Polri yang bermoral, profesional, modern dan mandiri untuk menuju egoverment dengan melakukan pembenahan berkelanjutan pada tataran instrumental struktural 
dan kultural khususnya dalam proses pelayanan melalui pelaksanaan program unggulan Polri (Quick Wins) yakni peningkatan layanan publik dan zero complain dengan meminimalisasi keluhan pelanggan serta menghilangkan praktek pencaloan terhadap pelayanan Regident Ranmor yang bertujuan untuk meningkatkan kepercayaan dan kecintaan publik kepada institusi Polri dalam waktu yang relatif cepat berdasarkan standar mutu. E-goverment dengan memanfaatkan teknologi informasi pada hakekatnya ditujukan untuk mengaplikasikan perubahan budaya Polri dalam memberikan pelayanan kepada masyarakat pada era digital saat ini sebagai pengaruh dari globalisasi (Dahlan, dan Marlina, 2013; Siregar, dkk., 2019; Yudianto, dkk., 2010).

Salah satu program Quick Wins adalah transparansi di bidang Regident Ranmor dengan mengedepankanpelayanan berbasis online system yang mengarah pada aspek kecepata, kemudahan terkait data ranmor dengan tetap memperhatikan aspek keamanan dan kenyamanan data ranmor. Hal ini dilandasi dengan beberapa pertimbangan sebagai berikut, Pertama, trancedent quality yaitu suatu kondisi ideal menuju keunggulan. Kedua, Product-based quality yaitu atribut produk yang memenuhi kualitas. Ketiga, Use based quality yaitu kesesuaian atau ketetapan dalam menggunakan produk (barangdan/atau jasa). Keempat, Manufacturing-based quality yaitu kesesuaian terhadap persyaratan-persyaratan standart. Kelima, Value-based quality yaitu derajat keunggulan pada tingkat harga yang kompetitif.

Mekanisme pleayanan publik di bidang regident ranmor dan identifikasi kendaraan bermotor khususnya BPKB pada dasarnya berorientasi pada terwujudnya good governece. Secara umum good governence mensyaratkan delapan karakteristik umum/dasar, yaitu partisipasi, orientasi pada konsensus, akuntabilitas, transparansi, responsif, efektif dan efesien, ekuiti (persamaan derajad), inklusifitas, serta penegakan/supremasi hukum. apabila diimplementasikan secara ideal, konsep ini diharapkan dapat memastikan pengurangan tingkat korupsi, pandangan kaum minoritas diperhitungkan dan suara dari mereka yang paling lemah dalam masyarakat didengar dalam proses pengambilan keputusan. Ia juga responsif terhadap masa kini dan kebutuhan masyarakat dimasa depan. Penjelasan singkat mengenai masing-masing krakteristik yaitu (Sumarto, 2003):

Participation dapat langsung maupun melalui institusi perwakilan yang legitimate dan harus imformatif dan terorganisir, Rule of law, good governence memerlukan sebuah kerangka legal atau hukum dan peraturan yang ditegakkan secara komprehensif, Transparancy mengandung arti pengambilan dan implementasi keputusan dilakukan dalam tata cara sesuai dengan hukum dan atauran, dapat pula diartikan bahwa informasi tersedia secara bebas dan dapat diakses langsung oleh masyarakat yang dipengaruhi oleh keputusan tersebut. Responsivess memerlukan institusi dan proses didalamnya yang mencoba untuk melayani semua stakholders dalam kerangka waktu tertentu yang sesuai. Consensus oriented, ada lebih dari satu aktor dan banyak sudut pandang dalam suatu komunitas. Good governence memerlukan mediasi dari kepentingan-kepentingan yang berbeda dimasyarakat dalam rangka mencapai sebuah konsensus umum yang merupakan kepentingan atau keputusan yang terbaik dapat dicapai untuk seluruh masyarakat. Equity and inclusiveness, yaitu keberadaan suatu masyarakat bergantung pada proses memastikan bahwa seluruh anggotanya merasa bahwa mereka memiliki kepentingan didalamnya dan tidak merasa dikucilkan dari maenstrim masyarakat tersebut. Effectiveness and efficiency, berarti output dari seluruh proses dan institusi tepat sasaran atau sesuai dengan kebutuhan masyarakat disamping efesien dalam pemanfaatan sumber daya untuk melakukannya. Accountability adalah salah satu kebutuhan utama dalam good governance.

Selanjutnya didalam pelaksanaan pelayanan publik di bidang registrasi dan identifikasi kendaraan bermotor harus berorientasi pada pencapaian "Capacity building" yang merupakan serangkaian strategi yang ditujukan untuk meningkatkan efesiensi, efektivitas, dan responsivitas dari kinerja pemerintah, dengan memusatkan perhatian kepada dimensi pengembagan sumber daya alam, penguatan organisasi, dan reformasi kelembagaan (Grindle, 1997). Konteks pengembangan sumber daya manusia, perhatian diberikan kepada pengadaan atau penyedia personel yang profesional dan teknis. Kegiatan yang dilakukan antara lain training, pemberian gaji/upah, pengaturan kondisi lingkungan kerja dan sistem perekrutan yang tepat. Peningkatan 
kemampuan menurut A. Fiszbein difokuskan pada kemampuan tenaga kerja, teknologi yang diwujudkan dalam bentuk organisasi atau kelembagaan, kemampuan "capital" yang diwujudkan dalam bentuk dukungan sumber daya, sarana, dan prasarana (Fiszbein, 1997). Menurut D. Eade merumuskan peningkatan kemampuan dalam tiga dimensi yakni individu, organisasi, network. (Eade, 1998) Nampaknya pengembangan dimensi individu, organisasi merupakan kunci utama atau titik strategis bagi perbaikan kinerja, tetapi masuknya dimensi network ini sangat penting karena melalui dimensi ini individu dan organisasi dapat belajar mengembangkan diri dan berinteraksi dengan lingkungan.

\section{Pelayanan Prima di Bidang Registerasi dan Identifikasi oleh Direktorat Lalu Lintas Polda Sumatera Utara Untuk Mewujudkan Akuntabilitas Pelayanan Publik.}

Polri sebagai bagian dari aparatur pemerintah yang memiliki tugas pokok sebagai pelindung, pengayom, pelayan masyarakat, (UU Kepolisian, 2/2002) senantiasa menjadi sorotan dan penilaian masyarakat. Setiap gerak gerik, sikap dan perilaku Polri dalam menjalankan tugas yang langsung bersentuhan dengan masyarakat terutama dalam memberikan pelayanan tentunya tidak lepas dari penilaian masyarakat baik positif maupun negatif. Penilaian tersebut membentuk suatu opini publik yang luas dan abstrak yang biasa disebut dengan citra.

Pencitraan negatif terhadap insitusi Polri saat ini disebabkan oleh adanya penilaian negatif masyarakat terhadap ketidakprofesionalan personil Polri dalam melaksanakan tugasnya disamping faktor-faktor lainnya di dalam lingkup insfrumental input (dari dalam) dan eksvrumental output (dari luar) yang mempengaruhi pelaksanaan tugas polri. Faktor-faktor inilah yang menjadi kendala dalam mewujudkan pencitraan positif terhadap insititusi Polri sehingga kurangnya kepercayaan masyarakat. Faktor dimaksud antara lain, performance personil Polri yang tidak profesional untuk memberikan pelayanan kepada masyarakat, sikap yang cenderung tidak mencerminkan sebagai pelindung, pengayom masyarakat, birokrasi yang berbelit-belit, pungutan liar serta sarana prasrana yang kurang mendukung yang berakibat kepada civil disobedience( ketidakpatuhan sosial) sehingga menghambat tugas Polri untuk memberikan pelayanan yang terbaik kepada masyarakat sesuai dengan harapan yang dicita-citakan untuk terwujudnya masyarakat madani (Hendarso,2009)

Dalam rangka mengakselerasi strategi membangun kepercayaan (trust building) masyarakat dan pencitraan positif terhadap institususi Polri untuk menjalankan tugas di bidang pelayanan publik khususnya Transparansi Penerbitan SIM, STNK, dan BPKB dengan sasaran memberikan pelayanan prima kepada masyarakat melalui penerbitan SIM, STNK, dan BPKB yang berlandaskan asas transparan, akuntabel, kepastian waktu, akurasi, keamanan, tanggung jawab, kelengkapan sarana dan prasarana, kemudahan akses, kedisiplinan, kesopanan dan keramahan serta kenyamanan. Disamping amanah yang diberikan oleh Undang-Undang Nomor 2 Tahun 2002 maka Direktorat Lalu Lintas Polda Sumatera Utara khususnya bidang registrasi dan identifikasi kendaraan bermotor melakukan berbagai kebijakan guna mengimplemetasikan kebijakan Kapolri dan Undang-undang Kepolisian yang dijadikan sebagai tolak ukur untuk keberhasilan penyelenggaraan manajemen sistem lalu lintas dan kepercayaan masyarakat. Tolak ukur manajemen sistem lalu lintas mensyaratkan Direktorat Lalu Lintas Polda Sumatera Utara sebagai organisasi jasa (pelayan atau service) dan sekaligus (tidak dapat dipisahkan) sebagai organisasi kekuasaan (power), sebagai organisasi jasa maka Direktorat Lalu Lintas Polda Sumatera Utara harus mematuhi standar umum dimana pengguna jasa memperoleh ketersediaan (availability) dan kepuasaan (satisfaction) sehingga akan tercapai pencitraan pelayanan publik sesuai dengan harapan. Adapun tujuan transparansi pelayanan publik dibidang SSB sesuai kebijakan Kapolri adalah meningkatkan kepercayaam dan kecintaan publik (masyarakat) kepada institusi (Polri) dalam waktu cepat dengan sasaran yakni merubah pola pikir dan budaya serta manajemen Polri. (Komisi kepolisian, 2009)

Adapun tujuan transparansi pelayanan publik dibidang SSB sesuai kebijakan Kapolri adalah meningkatkan kepercayaam dan kecintaan publik (masyarakat) kepada institusi (Polri) dalam waktu cepat dengan sasaran yakni merubah pola pikir dan budaya serta manajemen Polri. Secara terminologis citra diartikan suatu hal yang abstrak namun dapat dirasakan karena citra $\underset{w}{\stackrel{w}{W} h t t p: / / m a h e s a i n s t i t u t e . w e b . i d / o j s 2 / i n d e x . p h p / j e h s s}$ …mahesainstitut@gmail.com 106 
merupakan hasil dari penilaian baik atau buruk, seperti penerimaan dan tanggapan baik positif maupun negatif yang datang dari publik (Subandono, 2008).

\section{Upaya Dalam Menciptakan Akuntabilitas Pelayanan Publik Oleh Direktorat Lalu Lintas Polda Sumatera Utara.}

Pelayanan publik dapat diartikan sebagai melayani suatu jasa yang diperlukan oleh masyarakat dalam berbagai bidang seperti kesehatan, pendidikan, kesejahteraan, dan lain sebagainya (Sardjudin, 1997). Pelayanan publik atau dalam hal ini pelayanan masyarakat adalah suatu usaha yang dilakukan oleh seseorang dan atau kelompok orang atau instansi tertentu untuk memberikan bantuan dan kemudahan kepada masyarakat dalam rangka mencapai suatu tujuan tertentu(Sedarmayanti, 2009). Pada hakekatnya pelayanan publik adalah pemberian pelayanan prima kepada masyarakat yang merupakan perwujudan kewajiban aparatur pemerintah sebagai abdi masyarakat. Adapun yang menjadi asas-asas pelayanan publik adalah (Moenir: 1998) sebagai berikut:

Tranparansi yaitu pelayanan yang diberikan bersifat terbuka, mudah dan dapat diakses oleh semua pihak yang membutuhkan dan disediakan secara memadai serta mudah dimengerti. Akuntabilitas yaitu pelayanan yang diberikan dapat dipertanggung-jawabkan sesuai dengan peraturan perundang-undangan yang berlaku. Kondisional yaitu pelayanan yang diberikan sesuai dengan kondisi dan kemampuan pemberi pelayanan dengan tetap berpegang pada prinsip efisiensi dan efektivitas. Partisipatif yaitu dapat mendorong peran serta masyarakat dalam penyelenggaraan pelayanan publik dengan memperhatikan kebutuhan dan aspirasi serta harapan masyarakat. Kesamaan Hak yaitu pelayanan yang diberikan tidak diskriminatif dan tidak membedakan suku, ras, golongan, agama, jenis kelamin, serta status ekonomi. Keseimbangan Hak dan Kewajiban yaitu pemberi dan penerima pelayanan harus memenuhi hak dan kewajiban masing-masing pihak.

Adapun yang menjadi prinsip-prinsip pelayanan publik adalah kesederhanaan; kejelasan; kepastian waktu; akurasi; keamanan; tanggung jawab; kelengkapan administrasi; kemudahan akses; kedisiplinan, kesopanan, dan keramahan; serta kenyamanan. Ukuran keberhasilan suatu pelayan ditentukan oleh tingkat kepuasan penerima pelayanan. Kepuasan penerima pelayanan dapat dicapai apabila penerima pelayanan memperoleh pelayanan sesuai dengan yang dibutuhkan dan diharapkan. Oleh karena itu, setiap penyelenggara pelayanan secara berkala hendaknya melakukan survey indeks kepuasan masyarakat yang dilayaninya.

Pelayanan melalui peningkatan sumber daya layanan diharapkan terwujudnya pelayanan yang berbasis transparansi serta menciptakan pelayanan prima yang merupakan suatu tuntutan E- government, karena berorientasi pada kepuasan pelanggan untuk memenuhi standar penilaian kinerja unit pelayanan publik berbasis on line system. Direktorat Lalu Lintas Polda Sumatera Utara telah berupaya mewujudkan peningkatan pelayanan melalui suatu sistem manajemen mutu (SMM) dengan menerapkan prinsip-prinsip akuntabilitas, transparansi, fairness, kenyamanan dan keamanan, penerapan sistem dan metode yang lebih fleksibel dan tepat sasaran. Upaya sebagai suatu sistem manajerial ini diharapkan dilakukan secara konsisten, terus menerus dan berkelanjutan dengan memperhatikan kebutuhan dan harapan masyarakat, sehingga pelayanan Regindent Ranmor dapat memberikan kepuasan kepada masyarakat. Untuk mengukur tingkat kepuasan masyarakat didasarkan pada rasio keberhasilan penyelenggaraan pelayanan publik sesuai harapan, keberhasilan penyelenggaraan pelayanan ditentukan oleh tingkat kepuasan penerima pelayanan sesuai dengan kebutuhan.

Infrastruktur system dan standarisasi di dalam membangun organisasi menjadi bagian penting dalam wahana perubahan ke depan dalam mewujudkan kualitas kinerja personil Polri secara profesional yang erat kaitannya pada pelayanan publik sebagai suatu paradigma baru dalam penyelenggaraan pelayanan Kepolisian melalui peningkatan kualitas pelayanan publik kepada masyarakat,meningkatnya kapabilitas dan akuntabilitaskinerja birokrasi, serta terwujudnya pemerintahan yang bersih dan bebas KKN dengan harapanadanya perubahanmind set, culture set dan terbangunnya system yangterintegrasi dan kinerja yang berkualitas. Hal ini 
sejalan dengan program prioritas ke- 3 Kapolri yakni peningkatan profesionalisme anggota Polri sebagai salah satu dari penjabaran program Nawacita Kabinet Kerja Jokowi-JK. Profesionalisme disektor pelayanan publik akan terwujud apabila dilakukannya perubahan budaya pelayanan dengan sasaran terbangunnya penguatan institusi (institution strengthening) untuk pemantapan soliditas, terobosan kreatif (creative breakthrough) untuk peningkatan profesionalisme, dan peningkatan integritas (integrity improvement) untuk akselerasi revolusi mental.

Profesionalisme di bidang pelayanan publik perlu menjadi perhatian mengingat pelaksanaan pelayanan saat ini belum memenuhi standar yang efektif efesien dimana akan menjadi salah satu pemicu terjadinya keterlambatan pelayanan atau ketidakpastian dan muncul keresahan masyarakat yang berujung pada terbukanya peluang untuk melakukan penyimpangan dalam menepis ketidakpastian maupun keresahan masyarakat itu sendiri sehingga belum mampu untuk mengakselerasi Polri professional. Standar mutu sudah dilakukan dengan berbagai penyelarasan strategis dalam manajemen teknologi informasi yang ditranslasikan ke dalam kriteria seperti keunggulan kompetitif, ketepatan waktu pemenuhan layanan, kepuasan masyarakat, produktivitas tenaga kerja dan profitabilitas. Oleh karena itu diharapkan adanya perhatian, yaitu sebagai berikut:

Kemampuan Sumber daya manusia merupakan faktor yang sangat mempengaruhi sebuah organisasi. Untuk itu diharapkan Ditlantas Polda Sumut dalam pelaksanaan tugas didukung oleh sumber daya manusia, yang dapat dilihat dari aspek kuantitas dan kualitas yaitu, Kuantitas personel Sebagaimana yang diuraikan pada Bab III, bahwa jumlah Riil personel Ditlantas Polda Sumut melebihi dari DSPP yang dibutuhkan. Adanya kelebihan personel Polri di Ditlantas Polda Sumut yakni secara riil berjumlah 313 personel, sedangkan menurut DSPP seharusnya jumlah personel Polri yang dibutuhkan hanyalah 158 personel. Dengan memperhatikan data jumlah personel tersebut sebenarnya sudah jauh dari kebutuhan DSPP yang ada, apabila dibandingkan dengan jumlah permohonan registrasi dan identifikasi kendaraan bermotor yang terus meningkat setiap tahun. Hal ini tentunya akandirasakan masih sangat kurang dan tetap mempengaruhi kemampuan dan keberhasilan personel dalam melaksanakan tugas terutama untuk mengaplikasikan on line system standar mutu, karena semakin tingginya intensitas jumlah permohonan registrasi dan identifikasi kendaraan bermotor tanpa diimbangi dengan peningkatan jumlah personel akan semakin tingginya terjadinya penyalahgunaan standar mutu dan tidak efektifnya tindakan pengawasan terhadap pelaksanaan Regident Ranmor.

Menurut teori kompetensi, kualitas pengetahuan merupakan kompetensi yang kompleks untuk dapat melihat apakah seseorang dapat melakukan pekerjaan berdasarkan pengetahuan yang dimilikinya. Sehingga apabila ditinjau dari teori ini maka diharapkan terjadi suatu peningkatan kualitas personel sesuai dengan kemampuan/kompetensi yang mencakup aspek pengetahuan, keterampilan dan perilaku yang diharapkan sebagai berikut Aspek Pengetahuan (knowledge), Aspek Keterampilan (Skill), Pada aspek budaya (attitude).

Dukungan anggaran Direktorat Lalu Lintas Polda Sumatera Utara menyangkut terjaminnya pelaksanaan standar mutu belum dianggarkan secara optimal di dalam anggaran DIPA terutama peruntukan angggaran pengadaan alat dan ruangan untuk kendali mutu dan pengembangan aplikasi standar mutu yang berbasis on-line.Untuk itu diharapkan agar tersedianya anggaran secara optimal untuk mengoptimalkan kegiatan on line system standar mutu Regindent Ranmor. Apabila mengharapkan anggaran dari DIPA tentunya mengalami proses yang cukup panjang dan mengalami kendala pada penyusunannya, untuk itu diharapkan agar adanya penguatan sinergitas Direktorat Lalu Lintas Polda Sumut dengan Dispenda Sumut untuk dapat menganggarakan anggaran ini pada anggaran Penerimaan Negara Bukan Pajak (PNBP). Tersedianya anggaran secara tersendiri dari anggaran PNBP diharapkan dapat memberikan motivasi dengan pengadaan honor staf maupun personel yang mengawaki penginputan data registrasi dan identifikasi kendaraan bermotor berbasis on linesystem.

Kondisi Sumber Daya Sarana Prasarana Adapun kondisi sarana dan prasarana yang diharapkan menyangkut pengoptimalan on line system Regindent Ranmor adalah tersedianya sarana dan prasarana yang memadai antara lain adanya tempat dan ruangan serta alat yang tersedia untuk mengidentifikasi terselenggaranya standar mutu berbasis teknologi informasi  w mahesainstitut@gmail.com 108 
dengan maksud untuk dapat menghindari terjadinya celah penyalahgunaan standar mutu layanan antara lain dukungan perangkat lunak (software) dalam sistem teknologi informasi regident ranmor saat ini menggunakan Aplikasi Visual Basic Ver. 6.0 dan menggunakan SQL Server 2005 dengan fitur aplikasi yang kurang optimal, yaitu hanya untuk proses BBN 1, BBN 2, Cetak BPKB, Mutasi dan Kartu induk.

Metode yang digunakan untuk mengoptimalkan On Line System Regindent Ranmor untuk mengakselerasi Program E-Government, Diharapkan adanya revitalisasi penerapan standar mutu yang dilakukan dengan pengembangan penyelarasan strategis dalam manajemen teknologi informasi yang ditranslasikan ke dalam kriteria seperti keunggulan kompetitif, ketepatan waktu pemenuhan layanan, kepuasan masyarakat, produktivitas tenaga kerja dan profitabilitas, yaitu sebagai berikut, Penyelarasan teknologi informasi untuk mendukungan penerapan standar mutu Diharapkan dalam penerapan standar mutu pelayanan dapat menyelaraskan strategi teknologi informasi sebagai investasi teknologi informasi yang sudah dibangun harus sejalan dengan tujuan strategi dan membangun kapabilitas yang diperlukan untuk menghasilkan nilai tambah yang diharapkan untuk meningkatkan transparansi dan akuntabilitas pelayanan publik mencakup dua hal.

Pertama, meningkatkan mekanisme dan prosedur manajemen teknologi informasi yang diterapkan pada pelayanan regident ranmor pada perencanaan, yaitu: meningkatkan kegiatan perencanaan kebutuhan yang harus dicapai sesuai dengan visi dan misi pelayanan prima dengan menerapkan standar mutu n pengembangan teknologi informasi. Kedua, integrasi strategi aplikasi standar mutu dengan pengembangan teknologi informasi dengan penyelenggara Samsat Polda Sumut dan stakeholder.Melaluipenerapan standar mutu dengan pengembangan teknologi informasi diharapkan lebih meningkatkan penyelenggaan pelayanan publik dengan mengoptimalkan manajemen teknologi informasi melalui penerapan sistem dan metodenya yang dimanfaatkan secara maksimal guna meningkatkan transparansi dan akuntabilitas pelayanan publik sehingga mampu untuk memantapkan soliditas baik antar fungsi pada Samsat maupun antar Polda dan Mabes Polri dengan mengaplikasi pelayanan one day service.

\section{SIMPULAN}

Peran Direktorat Lalu Lintas dalam menciptakan akuntabilitas pelayanan publik didasarkan pada Undang-Undang Nomor 2 Tahun 2002 tentang Kepolisian Negara Republik Indonesia. Direktorat Lalu Lintas Polda Sumatera Utara khususnya bidang registrasi dan identifikasi kendaraan bermotor melakukan berbagai kebijakan guna mengimplemetasikan kebijakan Kapolri dan Undang-undang Kepolisian yang dijadikan sebagai tolak ukur untuk keberhasilan penyelenggaraan manajemen sistem lalu lintas dan kepercayaan masyarakat. Tolak ukur manajemen sistem lalu lintas mensyaratkan Direktorat Lalu Lintas Polda Sumatera Utara sebagai organisasi jasa (pelayan atau service) dan sekaligus (tidak dapat dipisahkan) sebagai organisasi kekuasaan (power), sebagai organisasi jasa maka Direktorat Lalu Lintas Polda Sumatera Utara harus mematuhi standar umum dimana pengguna jasa memperoleh ketersediaan (availability) dan kepuasaan (satisfaction) sehingga akan tercapai pencitraan pelayanan publik sesuai dengan harapan.

Upaya yang dilakukan untuk mengatasi hambatan dalam pelaksanaan akuntabilitas pelayanan publik di Direktorat Lalu Lintas Polda Sumatera Utara antara lain: Pertama, mengembangkan program kegiatan terobosan kreatif melalui: Pertama, mengembangkan layanan Regindent Ranmor secara on line dengan berbasis web dan android. Kedua, mengembangkan layanan e-document berbasis ERI. Kedua, mengembangkan bentuk-bentuk kerjasama dengan stakeholder guna meningkatkan transparansi dan akuntabilitas pelayanan publik di dalam pelayanan Regindent Ranmor berbasis on line, antara lain: 1). bekerja sama dengan pemerintah daerah dalam integrasi sistem data base dengan data base regiden ranmor yang valid untuk dimanfaatkan secara luas untuk mendukung kepentingan instansi terkait. 2). bekerja sama dengan pihak ketiga dalam pembuatan Aplikasi Android Samsat. Untuk memudahkan masyarakat dalam bertransaksi secara online maupun dalam memberikan informasi tentang pelayanan samsat 
secara on line. 3). bekerja sama dengan media massa baik elektronik maupun cetak untuk meningkatkan iklan layanan masyarakat tentang program terobosan pelayanan samsat. Untuk meningkatkan informasi layanan samsat kepada masyarakat. 4). melakukan kerjasama dengan vendor yang ditunjuk untuk melakukan pendampingan operatorisasi on line.

\section{DAFTAR PUSTAKA}

Fiszbein, A. (1997. The emergence of local capacity, World Development, ( Vol. 25(7), Lesson from Columbia Hendarso, B, (2009). Prioritas Program Citra Polri, ditulis oleh Komisi Kepolisian, tanggal 29 Januari, 2009

Nasution, B. (2003), Metode Penelitian Hukum Normatif dan Perbandingan Hukum, Makalah, disampaikan dalam Dialog Interaktif tentang Penelitian Hukum dan Hasil Penulisan Penelitian Hukum pada Majalah Akreditasi, Fakultas Hukum USU, Medan, tanggal 18 Februari 2003.

Countries, M.A. (1997). : Harvard Institute for International Development, Boston, 1997.

Eade, D. (1988). Capacity Building: An approach to people-centered development, UK: Oxfam, GB, Oxford

Moenir, H. A. S. (1998). Manajemen Pelayanan Umum di Indonesia,.Bumi Aksara, Jakarta,

Hetifah. (2003). Sumarto, Inovasi, Partisipasi dan Good Governance, Yayasan Obor Indonesia, Jakarta,

Sardjudin, K.N. (1997), Konsepsi Pendayagunaan Aparatur Daerah. Bandung: LAN RI.

Zweigert, K. dan Kotz, K, (1997). Introduction to Comparative Law, Vol. 1.

Grindle, M.S. (Ed.), (2000). Getting Good Government: Capacity Building in the Public Sectors of Developing Rangkuti, F, (2008). Analisis SWOTs Teknik Membedah Kasus Bisnis; Reorientasi Konsep Perencanaan strategis Untuk Menghadapi Abad 21, PT. Gramedia Pustaka Utama, Jakarta.

Sedarmayanti, (2000). Restrukturisasi dan Pemberdayaan Organisasi Untuk Menghadapi Dinamika Perubahan Lingkungan, Mandar Maju, Bandung

Subandono, H.M.P. (2008). Tentang Pencitraan Polri, Sespim Polri.

Mendelson, W. (1979), "Law and Development of Nations," The Jounal of Politics, 3 (2): 223

Andrisman, T. (2007). Hukum Pidana, Universitas Lampung. Bandar Lampung.

Christine S.T. Kansil, C.S.T Kansil. (2002). Hukum dan Tata Negara Republik Indonesia Cetakan Ketiga. Rineka Cipta. Jakarta. halaman 90.

Dahlan, M., dan Marlina, (2013), Analisis Putusan Hakim Terhadap Tindak Pidana Lalu Lintas yang Menyebabkan Kematian (Studi Putusan di Pengadilan Negeri Sigli), Mercatoria, 6 (1): 104-116

Harahap M.Y. (2010). Pembahasan Permasalahan dan Penerapan KUHAP. Cetakan ke 12. Sinar Grafika.

Ilyas, A. (2012). Asas-Asas Hukum Pidana, Rengkang Education Yogyakarta. Yogyakarta.

Kepolisian Negara Republik Indonesia Akademi Kepolisian. 2009. Fungsi Teknis Lalu Lintas, Kompetensi Utama. Medan.

Lopa, B. (1999). Pertumbuhan Demokrasi (Penegakan Hukum dan Perlindungan Hak Asasi Manusia). PT. Yarsif Watampone. Jakarta.

Mahrus, A. (2012). Dasar-Dasar Hukum Pidana. Jakarta: Sinar Grafika.

Moeljatno, (2008). Asas-Asas Hukum Pidana. Jakarta: Rieneka Cipta

Prodjodikoro, W. (2014). Asas-Asas Hukum Pidana di Indonesia. Refika Aditama. Bandung.

Rusli. M. (2013). Lembaga Pengadilan Indonesia Beserta Putusan Kontroversial, UII Pres, Yongyakarta.

Sadjijono. (2011). Hukum Administrasi, Laksbang Presindo. Yogyakarta.

Samapto, S.A., (2009). Penyelesaian Perkara Pidana di Luar Pengadilan Terhadap Dugaan Kejahatan Pasal 359 KUHP Dalam Perkara Lalu Lintas, STMIK AMIKOM. Yongyakarta.

Siregar, R.D.W, Mubarak, R \& Zulyadi, R. (2019). Peranan Kepolisian Dalam Penerapan Restorative Justice Terhadap Kecelakaan Lalu Lintas Di Wilayah Polsek Deli Tua (Studi Kasus Polsek Delitua). JUNCTO, 1(2) 2019: 150-157,

Situmorang, B. (2011). Sejarah Perkembangan Hukum Lalulintas. Fakultas Hukum USU. Medan.

Soekamto, S. (2004). Faktor-faktor yang Mempengaruhi Penegakan Hukum. Raja Grafindo Persada. Jakarta.

Soekanto, S. (1989). Suatu Tinjauan Sosiologi Hukum Terhadap Masalah-masalah Sosial, Bandung : Citra Aditya Bakti. Halaman 58

Winarno. 1989. Hukum Dan Lalu Lintas di Jalan Raya. Erlangga. Jakarta.

Yudianto, E., Marlina, dan Arif, (2010), Peran Kepolisian Republik Indonesia dalam Sosialisasi UndangUndang Nomor 22 Tahun 2009 tentang Lalu Lintas dan Angkutan Jalan (Studi pada Markas Kepolisian Daerah Sumatera Utara), Mercatoria, 3 (1): 20 - 33.

Undang-Undang Dasar Negara Republik Indonesia Tahun 1945

Undang-Undang No. 14 Tahun 1992 tentang Lalu Lintas dan Angkutan Jalan,

Undang-Undang Nomor 22 Tahun 2009 tentang Lalu Lintas dan Angkutan Jalan 